\title{
The Effect of Advertising Exposure on Attitude Toward the Advertising and the Brand and Purchase Intention in Instagram
}

\author{
Paragitha Kusuma Wardhani \\ Master of Management \\ Faculty of Economics and Business, Universitas Indonesia \\ Jakarta, Indonesia \\ paragithakusuma@gmail.com
}

\author{
Dr. M. Gunawan Alif \\ Master of Management \\ Faculty of Economics and Business, Universitas Indonesia \\ Jakarta, Indonesia \\ mgunawanalif@gmail.com
}

\begin{abstract}
The steady rise in use of social media for advertising has raised several questions about the important features of advertisement that could attract the customers. The present study investigates the effectiveness of advertising exposure on Instagram, a widely used social media in Indonesia, with regard to the customers' behavioral attitudes toward the brand and purchase intention. This quantitative research conducted through a survey of over 260 respondents via self-administered structured questionnaires. Data were analyzed using structural equation modeling (SEM) using LISREL. The most powerful influences that exist between variables that measure ad exposure are that of entertainment and informativeness on attitude toward the advertising. In addition, compared to the influence of attitude toward the brand, attitude toward the advertising has a significant effect on purchase intention. This study focuses only on Instagram users and the advertising campaign run in Indonesia. Despite this limitation, the study findings enable marketers to enhance the effectiveness of their advertising campaign to reach the targeted ROI through emotional appeals, creativity, information, entertainment features to increase customer's positive attitude toward the advertising, the brand, and purchase intention. The study contributes to the literature of marketing communication, specifically in advertising, by enabling researchers to understand the social media advertising effectiveness from emotional appeals, creativity, information, entertainment aspects.
\end{abstract}

Keywords-social media advertising, purchase intention, attitude toward the advertising, attitude toward the brand, advertising effectiveness

\section{INTRODUCTION}

The rapid rise of technology has led to a significant shift in the advertising world from traditional to social media [1]. Starting from "Open Diary" by Bruce and Susan Abelson and supported by high-speed internet connectivity, social networking sites such as MySpace and Facebook was built and later called social media [2]. According to Ellison, Steinfield, and Lampe [3], social networking sites is aare virtual web-based networks where individual can form and maintain their social connections. Earlier, the only function of the social media was to share information between users. In the present day, due to development in technology, marketers can use social media to promote products and services. Thus, the value of social media is continuously increasing due to the growth of audiences and sophistication of platforms. The ability of social networking sites to target specific customers according to their demographic, psychology, behavior, and needs are useful for marketers; hence, they decided to shift their marketing budget spending from traditional media to social networking sites. According to eMarketer data [4], total media ad spending in Indonesia for digital and mobile internet advertising has continued to increase from 2014 to 2019, where digital advertising includes search engine, email marketing, and social media. Thus, Indonesia ranks second after Argentina in the development of advertising [4]. Instagram is one of the popular social media used by marketers to promote their product or service in Indonesia.

As one of the media of promotional mix used in the integrated marketing communication, social media advertising can be divided into free and paid advertising [5]. Nielsen report [6] stated that social media advertising is useful for branding. As a place to advertise a product or service, a brand could use social media to deliver the marketing message to a specifically targeted audience [5]. Therefore, marketers could maximize the advertising budget with the distribution of content to a specific audience [7]. The interactions between consumers on social media could form the electronic word-of-mouth (eWOM). Whether positive or negative, eWOM is a review of a product or services of a brand or a company available for many on the internet as well as an opportunity to communicate between consumers [8][9]. The features offered by social media, such as oneclick social plug-ins, gives users the opportunity to communicate their interest regarding an advertising [1]. Furthermore, eWOM from social media advertising could increase brand awareness and revenue [10]). Moreover, social media is a great place for a brand to promote its product due to the increasing amount of time spent by consumers on social media. Demographically, adults of age 18 and above show an increase of $36 \%$ of the time spent on social media [11].

Following Facebook [12], Instagram had more than 2 million active advertisers in September 2017 [13]. In Indonesia, Instagram has 45 million active users. According to Country Director of Facebook, Sri Widowati, and Product Marketing Director of Instagram, Susan Rose, Indonesia's Instagram users form the largest community in Asia Pacific, which can be utilized by brands to build a relation with customers through creative content [14]. With majority of the users are in the age group of 18 to 34 years, Instagram users 
are using the platform to check online shopping accounts and for entertainment purposes [15].

Among other social media, such as Twitter and Facebook, Instagram is a platform where customer's involvement is important due to its visual attraction. Moreover, at least $75 \%$ of Instagram users who see an advertisement will visit the advertiser's website or click the "like" button on the advertisement [12]. Based on previous studies, social media features such as like and share could be a benchmark of advertising effectiveness, which could provoke eWOM and a positive response for the advertisement [16][17][10]. The distribution of information on social media using these features shows an engagement of an advertisement expected by marketers [18][19]. However, according to a previous study by Lee and Hong [10] on Facebook advertising, to achieve advertising effectiveness on social media, informativeness and advertising creativity are the two attributes that could foster empathy through the onclick social plug-ins. Dehghani, Niaki, Ramezani, and Sali [20] mentioned that entertainment and customization in an advertisement could influence the value of the advertisement, especially in YouTube advertising. Furthermore, Lee and Hong [10] concluded that informativeness, advertising creativity, entertainment, and customization are the antecedents of attitude toward the advertising.

Based on the earlier studies, the present study adopts a quantitative method using a self-administered questionnaire to Instagram users in Indonesia. The study aims to find the indicators of an advertising exposure in social media advertising, which could influence the attitude toward the advertising and the brand and provoke a purchase intention among customers. The primary data used in this research is acquired from a survey and the secondary data is taken from journals, books, websites, and articles regarding the study. The study result can be used by marketers to evaluate the importance of advertising exposure in social media advertising that highlights emotional appeal, informativeness, advertising creativity, and entertainment aspects.

\section{LITERATURE REVIEW}

\section{A. Social Media Advertising}

The role of social media has been evolving to facilitate the needs and wants of the users. From sharing everyday stories, knowledge, interest, and hobbies to selling products and advertisement of a product or service, social media is now the place where people search for new information online, which is formed, distributed, and used by customers to increase their knowledge about product, service, brand, or other issues. There are different types of social network and sharing sites [21]. Social network sites include Facebook, Twitter, and Instagram, while social sharing sites include YouTube and Flickr [21].

According to the Internet Advertising Bureau [22], social media advertising is defined as the web-based advertising that provides visual information to a social media user. Rodgers and Thorson [23] stated that social media could be used to maximize the marketing, public relation, mobile, and offline strategies through the advertisement content. Moreover, Rodgers and Thorson [23] defined social media advertising as any kind of content available online, which includes any form of persuasion and is distributed through social media platform so that an internet user can access, share, involve, and together create the content. Behavior targeting is one way to reach customers. Consumer behavior could be targeted by the marketers through display ad, promoted content, and plug-ins [23].

To increase brand awareness and traffic of social media, a company or brand needs to reach various communities in social media using advertising [5]. Besides, social media advertising could be used to listen to customers' complaints about their experience in using the product or service. The benefits of social media leads its greater use compared to traditional media.

The positive perception of a social media user who sees the advertising is very important. Studies have shown that positive eWOM from customers could defined the attitude toward social network advertising [5]. Moreover, a study by Chandra, Goswami, and Chouhan [24] showed that customers' purchase decision emerge from social media advertising that results in price rivalry [25].

\section{B. Emotional Appeals}

Emotional appeals can be in any form of positive feelings and emotion, such as love and pride, and negative feelings such as fear and guilt [26] mentioned that two types of emotional appeal motivate a purchase. Other than a purchase, emotional appeal could also provoke eWOM on social media [27].

The motivational message relevant to an individual evokes emotional appeals and responses to it. Thus, viral advertisement messages on online media contain stronger emotional appeals [28]. Marketers need to focus on creating advertisement with emotional appeal. An advertisement could build its emotional appeals through graphic or color creation, effective message, or celebrity endorsement [29].

\section{Informativeness}

A brand message could be delivered through digital advertisement. However, a customer's trust of a brand and their interpretation will determine the delivery process of the advertisement information [30]. Advertisement information is vital for a product when there are many substitute products [31]. He mentioned that a brand that uses an informative advertisement could have two possibilities. First, the informative advertisement could be used to reach customers and competitors. Second, the advertisement could grab the competitor's customers. Marketers can give information to help various customers to choose a product or service through informativeness of an advertisement [32] [33]. Moreover, Ducoffe [34] stated that the more informative an advertisement, the more it shows the ability of a brand about alternative product.

\section{Advertising Creativity}

Creativity in an advertisement is one of the key features because of its ability to increase the ad effectiveness [35]. Creativity is defined by Reinartz and Peter [36] as the elements an advertisement that are different, unique, and peculiar. They also mentioned five dimensions of advertising creativity: originality, flexibility, elaboration, synthesis, and artistic value.

Creativity is increasingly important, especially on Instagram owing to its accentuation in visual aspect. 
Nevertheless, creativity value might be perceived differently by each individual or is frequently called relative. One may evaluate an advertisement and consider it least creative, while another may consider it highly creative [35]. In a study by Reinartz and Peter [36], the creativity value is shown differently, depending on the product category. The study also mentioned that the advertisement that has a high creativity value may result in double sales value compared to those that are not creative [36].

According to Smith and Yang [35], there are three characteristics of advertising creativity relevance, difference, and effectiveness. There are differences in creativity when the advertisement is original. Relevance of an advertisement is apparent when it has a special meaning to the customer. It could be defined as ad-consumer relevance and brandconsumer relevance. Finally, creativity value in an advertisement is apparent when it could reach its objective [35]. Creativity could also increase the attitude toward the advertising and motivate consumers to process the advertisement. Both could bring a positive effect to an advertiser's brand [37].

\section{E. Entertainment}

Each individual has a different intention in using the social networking sites. Some use it for fun and tranquility, while some as a pass-time activity [38]. According to Taylor, Lewin, and Strutton [39], an advertisement in social media that has entertainment value has more opportunity to influence the attitude of customer toward the advertising. Thus, a brand that uses entertainment in their advertisement will attract more customers. When an advertisement in social media uses entertainment, there is a likely positive impact on the attitude toward the advertising. Moreover, advertisement that entertains a viewer makes it easier for them to recall, which could result in a higher purchase intention [40].

\section{F. Attitude}

There is abundant theory on attitude. Attitude is a vital observation for marketers, especially in terms of advertising due to its ability to represent the feelings of each individual toward an object through simple description [41]. Attitude is also important because marketers could observe the behavioral tendency and positive and negative feelings toward an object [41].

\section{G. Attitude toward the Advertising}

Through the cognitive response model, the communication process in an advertisement could be defined as three thoughts: product/message thoughts, source-oriented thoughts, and ad execution thoughts. Ad execution thoughts sometimes do not relate to the advertising message, except the affective reaction when someone sees the advertisement. Thus, visual creativity in an advertisement is very important [41].

According to MacKenzie and Lutz [42], attitude toward the advertising is one of many forms of individual response, whether good or bad, to an advertisement as a stimulus. This could occur when a consumer is exposed to an advertisement. Previous studies mentioned that attitude toward the advertising is the intermediary of a response to an advertisement [42].

\section{H. Attitude toward the Brand}

According to Davtyan and Cunningham [43], the concept of attitude toward the brand is the whole evaluation by customers about the brand. Therefore, the more the customer sees the brand, their attitude will most likely be affected [44]. The possibility of brand purchase is higher if consumers already have a positive attitude toward the advertiser's product, service, or brand.

When there is brand familiarity, consumers tend to have a positive attitude toward the brand, which also increase the chances of purchase intention [45]. Positive attitude toward a brand could be gained from perceived quality, customer value, and customer satisfaction [45]. Previous study by Rosselli, Skelly, and Mackie [46] mentioned that emotional aspect, whether positive or negative, helps a customer to relate to the attitude toward the brand product, or service. These could change the purchase decision of the customer [1].

\section{Purchase Intention}

There are five steps in the purchase intention: problem recognition, information search, evaluation of alternatives, purchase decision, and post-purchase behavior. However, not all customers go through the whole process. In the evaluation of alternatives, customer's purchase intention is higher. Purchase intention is based on the purchase motives based on the brand attributes being considered [41].

\section{- Problem recognition}

The emergence of a problem or customer needs is the first step of the purchase intention. It could be caused by internal or external forces. Internal force occurs when the normal needs rise to the highest level such that the purchase intention arises. Marketers need to identify which condition provokes the customers' needs in order to form the appropriate marketing strategy [44].

\section{- Information search}

The unfulfilled needs will lead to customers seeking information and being more responsive to any kind of stimulation regarding the fulfillment of the needs. Kotler and Keller [44] categorized the sources of customer information into personal, commercial, public, and experimental. Every source of information has a different function in terms of influencing the purchase intention. Commercial source is taking its informational function, while personal source take the legitimization and evaluation function [44].

\section{- Evaluation of alternatives}

After customers gather all the necessary information, they use it to identify and evaluate any alternatives. In this step, customers process the information they acquire to evaluate and make the final decision. This process is important for the customer so they will receive the best of everything in terms of quality, price, time, shipping, and other factors that they consider important. Producer need to understand how customers analyze information acquired to the final attitude about a product and its purchase intention. At this stage, rational 
advertisement that touches the emotion of customer is crucial because it could provoke a purchase intention for the brand [44].

- Purchase decision

The purchase decision is the stage where customer actually buys the product. At this stage, a customer chooses the product among various brands. There are five subdecisions when it comes to a purchase decision: the product, the brand, who they bought it from, quantity, and when to buy the product. These decisions do not always come in order. It depends on the purchase of the product needed.

- $\quad$ Post-purchase decision

The post-purchase decision is the final step to know the customer satisfaction after the purchase. Therefore, the duty of marketers does not stop at sales. Customer's satisfaction comes only after they purchase and use the product. The relation between the customer expectation and the product will greatly impact the customer satisfaction

\section{Proposed FrameWORK OF StUdy AND HyPOTHESIS DEVELOPMENT}

Emotional appeals, informativeness, advertising creativity, and entertainment are the four aspects that serve as the benchmark for advertisement effectiveness. Various earlier studies have proven that these four aspects as antecedents of the attitude toward the advertising [34][36][39]. Ads that emphasize emotional aspect are increasingly used by marketers. Emotional aspect is used because it can elicit affective reactions from consumers that also involve consumer engagement of the brand as a measure of the success of the ad [41].

Consumer purchasing decisions often occur as a result of informative advertising [47]. Advertising Informativeness is crucial because it can shape consumer attitudes toward different types of advertising channels; one of which is advertising on social media [39]. Lee and Hong [10] stated that the attention and motivation of individuals who see ads will be higher because of the aspect of informativeness. Consumer motivation to process information and attitude toward the advertising will increase if the advertisement has creativity; therefore, the relationship of advertising creativity with the effectiveness of advertising is very strong [10][37].

The entertainment aspect of ads has higher values in social media compared to other advertising platform [48]. The relaxation effect expected by the audience are the reasons behind the importance of the entertainment aspect, especially for the audience in the age group of 19 to 24 years [48]. In addition, according to Taylor, Lewin, and Strutton [39], advertising on social media could attract a significant effect on attitude toward the advertising from consumers.

H1. Emotional appeals from Instagram ads have a positive effect on attitude toward the advertising

H2. Emotional appeals from Instagram ads have a positive effect on attitude toward the brand

H3. Informativeness of Instagram ads has a positive effect on attitude toward the advertising
H4. Informativeness of Instagram ads has a positive effect on attitude toward the brand

H5. Advertising creativity from Instagram ads has a positive effect on attitude toward the advertising

H6. Advertising creativity from Instagram ads has a positive effect on attitude toward the brand

H7. Entertainment from Instagram ads has a positive effect on attitude toward the advertising

H8. Entertainment from Instagram ads has a positive effect on attitude toward the brand

Belch and Belch [41] stated that when an individual is exposed to an advertisement, their cognitive responses can be assessed by marketers to understand how the individual is processing an advertisement. The cognitive response approach of individuals reading, seeing, or hearing an advertisement can help marketers assume how the individual is receiving or reacting to the advertisement being viewed. Thus, marketers can observe whether the ads are accepted by target audience. This approach can link the response to advertising on attitude toward both advertising and brand and purchase intentions.

Ad exposure has no direct effect on products or messages when they appear and are seen by the target audience. However, there are affective reactions that can show the consumer's attitude toward advertising. Execution of an advertisement can generate positive or negative thoughts in consumers' minds. It is important to understand these thoughts because it can show the consumers' attitude toward the advertising and toward the brand. Both of these are important and very useful for marketers. This is due to attitude toward both the advertising and the brand as a measuring tool to see how effectively the ads are displayed. An affective reaction from the consumer can affect the achievement of the effectiveness of advertising, which can then be a boost to the emergence of purchasing intentions from consumers of a brand.

H9. Attitude toward the brand advertising in Instagram has a positive effect on attitude toward the advertising

H10. Attitude toward the advertising from Instagram ads has a positive effect on purchase intention

H11. Attitude toward the brand from Instagram ads has a positive effect on purchase intention

Therefore, the research model for this study is as shown in Figure 1.

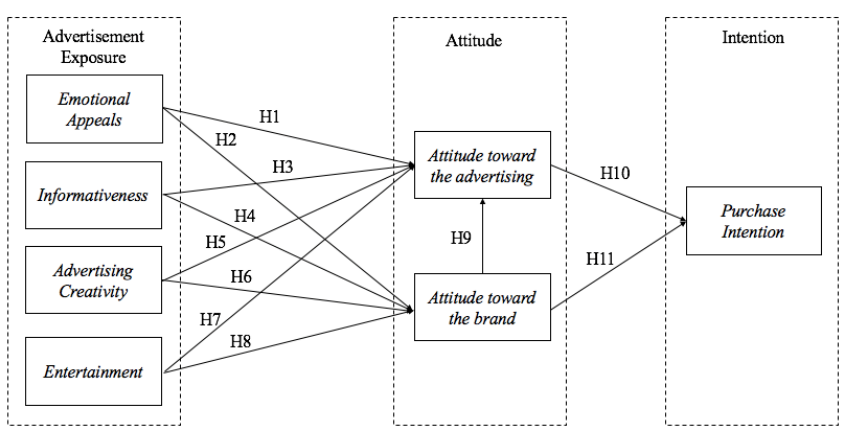

Fig. 1. Research Model 


\section{RESEARCH METHODOLOGY}

This study uses quantitative approach using structural equation modeling (SEM) to analyze the effect of advertising exposure dimensions (emotional appeals, informativeness, advertising creativity, and entertainment) on attitude and purchase intention of Instagram users in Indonesia. A selfadministered questionnaire is used to gather primary data, which contain the modified version of advertising exposure of an advertisement based on literature review. There are 14 questionnaire items on the advertising exposure[10][48][5], 7 items on the attitude [5], and four items on the purchase intention [5]. The study population is the Instagram users in Indonesia, while the sample focuses on Instagram users of the aged 16 to 35 years. The selection of the population is relatable due to the data of the leading active Instagram users are within the age range.

The research model is developed using the main variables that evaluate the effectiveness of the exposure of the ad, which are emotional appeals, informativeness, advertising creativity, entertainment, attitude toward the advertising, attitude toward the brand, and purchase intention. The definition of each variables are describe in Table I.

TABLE I. OPERATIONAL DEFINITION

\begin{tabular}{|c|c|c|}
\hline Variables & Definition & Measures \\
\hline $\begin{array}{l}\text { Emotional } \\
\text { appeals [49][50] }\end{array}$ & $\begin{array}{l}\text { Emotional appeals are any form of } \\
\text { feelings and emotions whether it is } \\
\text { positive such as joy, love, proud or } \\
\text { negative such as fear and guilt } \\
\text { [26]. }\end{array}$ & $\begin{array}{l}\text { Likert Scale 1- } \\
6\end{array}$ \\
\hline Variables & Definition & Measures \\
\hline $\begin{array}{l}\text { Informativeness } \\
{[48][51]}\end{array}$ & $\begin{array}{l}\text { Informativeness of an } \\
\text { advertisement is the ability of an ad } \\
\text { to inform consumers regarding the } \\
\text { alternative product [34] }\end{array}$ & $\begin{array}{l}\text { Likert Scale 1- } \\
6\end{array}$ \\
\hline $\begin{array}{l}\text { Advertising } \\
\text { creativity [52] }\end{array}$ & $\begin{array}{l}\text { An advertisement has the creativity } \\
\text { aspect when it is different, original, } \\
\text { unique, and unusual which shown } \\
\text { in the elements of the } \\
\text { advertisement [36]. }\end{array}$ & $\begin{array}{l}\text { Likert Scale 1- } \\
6\end{array}$ \\
\hline $\begin{array}{l}\text { Entertainment } \\
{[39][53]}\end{array}$ & $\begin{array}{l}\text { The entertainment aspects of an } \\
\text { advertisement indicate the ability } \\
\text { of the advertisement to entertain, } \\
\text { give enjoyment, and pleasure to the } \\
\text { audience (Lee \& Choi, 2005) }\end{array}$ & $\begin{array}{l}\text { Likert Scale 1- } \\
6\end{array}$ \\
\hline $\begin{array}{l}\text { Attitude toward } \\
\text { the advertising } \\
{[54]}\end{array}$ & $\begin{array}{l}\text { Attitude toward the advertising is } \\
\text { one of many form where } \\
\text { individuals give response, whether } \\
\text { it is positive or negative, to an } \\
\text { advertisement given as the stimulus } \\
\text { and this could happen when } \\
\text { individuals are expose to the } \\
\text { advertisement [42] }\end{array}$ & $\begin{array}{l}\text { Likert Scale 1- } \\
6\end{array}$ \\
\hline $\begin{array}{l}\text { Attitude toward } \\
\text { the brand } \\
{[55]}\end{array}$ & $\begin{array}{l}\text { Attitude toward the brand is the } \\
\text { whole evaluation of customers or } \\
\text { consumers toward the brand [43]. } \\
\text { The positive attitude of a brand } \\
\text { could be gathered from the } \\
\text { perceived quality, customer value, } \\
\text { and customer satisfaction. [45]. }\end{array}$ & $\begin{array}{l}\text { Likert Scale 1- } \\
6\end{array}$ \\
\hline $\begin{array}{l}\text { Purchase } \\
\text { intention } \\
{[56]}\end{array}$ & $\begin{array}{l}\text { The purchase intention could } \\
\text { happen based on the attribute or } \\
\text { characteristic of a brand being } \\
\text { considered [41]. }\end{array}$ & $\begin{array}{l}\text { Likert Scale 1- } \\
6\end{array}$ \\
\hline
\end{tabular}

\section{RESULT AND DISCUSSION}

The study measures are first examined for validity and reliability. The validity of the measures is confirmed when the value of Kaiser-Mayer Olkin exceeds 0.5, Bartlett's Test of Sphericity is less than 0.05 , and component matrix value is more than 0.5 [57]. The reliability of the measures is confirmed if the value of Cronbach's alpha is more than 0.6 [57]. According to the result of validity and reliability tests, all the measures used to examine the exposure of advertisement and its effect on attitude toward brand, attitude toward advertising, and purchase intention are confirmed to be valid and reliable. The validity and reliability test of this study is shown Table II.

TABLE II. V VALIDITY AND RELIABILITY TEST

\begin{tabular}{|c|c|c|c|c|c|c|}
\hline $\begin{array}{l}\text { N } \\
\text { o. }\end{array}$ & Variables & $\begin{array}{c}\text { Variabl } \\
\text { es } \\
\text { Indicato } \\
\text { rs }\end{array}$ & $\begin{array}{c}\text { Kaiser } \\
- \\
\text { Mayer } \\
\text { Olkin } \\
\text { (KMO) }\end{array}$ & $\begin{array}{c}\text { Bartlet } \\
\text { t's } \\
\text { Test of } \\
\text { Spheri } \\
\text { city }\end{array}$ & $\begin{array}{c}\text { Compon } \\
\text { ent } \\
\text { Matrix } \\
\text { (factor } \\
\text { loading) }\end{array}$ & $\begin{array}{l}\text { Cronb } \\
\text { ach's } \\
\text { Alpha }\end{array}$ \\
\hline \multirow{3}{*}{1} & \multirow{3}{*}{$\begin{array}{l}\text { Emotional } \\
\text { appeal }\end{array}$} & 1. EA1 & \multirow{3}{*}{0,700} & \multirow{3}{*}{0,000} & 0,886 & \multirow{3}{*}{0,871} \\
\hline & & 2. EA2 & & & 0,873 & \\
\hline & & 3. EA3 & & & 0,937 & \\
\hline \multirow{4}{*}{2} & \multirow{4}{*}{$\begin{array}{l}\text { Informati } \\
\text { veness }\end{array}$} & 1. INF1 & \multirow{4}{*}{0,806} & \multirow{4}{*}{0,000} & 0,823 & \multirow{4}{*}{0,888} \\
\hline & & 2. INF2 & & & 0,886 & \\
\hline & & 3. INF3 & & & 0,933 & \\
\hline & & 4. INF4 & & & 0,828 & \\
\hline \multirow{4}{*}{3} & \multirow{4}{*}{$\begin{array}{l}\text { Advertisin } \\
\mathrm{g} \\
\text { creativity }\end{array}$} & 1. $\mathrm{AC} 1$ & \multirow{4}{*}{0,710} & \multirow{4}{*}{0,000} & 0,893 & \multirow{4}{*}{0,907} \\
\hline & & 2. $\mathrm{AC} 2$ & & & 0,904 & \\
\hline & & 3. $\mathrm{AC} 3$ & & & 0,898 & \\
\hline & & 4. $\mathrm{AC} 4$ & & & 0,863 & \\
\hline \multirow{3}{*}{4} & \multirow{3}{*}{$\begin{array}{l}\text { Entertain } \\
\text { ment }\end{array}$} & 1. ENT1 & \multirow{3}{*}{0,725} & \multirow{3}{*}{0,000} & 0,905 & \multirow{3}{*}{0,932} \\
\hline & & 2. ENT2 & & & 0,947 & \\
\hline & & 3. ENT3 & & & 0,962 & \\
\hline \multirow{4}{*}{5} & \multirow{4}{*}{$\begin{array}{l}\text { Attitude } \\
\text { toward the } \\
\text { advertisin } \\
g\end{array}$} & 1. AAD1 & \multirow{4}{*}{0,802} & \multirow{4}{*}{0,000} & 0,895 & \multirow{4}{*}{0,925} \\
\hline & & 2. AAD2 & & & 0,899 & \\
\hline & & 3. AAD3 & & & 0,923 & \\
\hline & & 4. AAD4 & & & 0,932 & \\
\hline \multirow{3}{*}{6} & \multirow{3}{*}{$\begin{array}{l}\text { Attitude } \\
\text { toward the } \\
\text { brand }\end{array}$} & 1. $\mathrm{AB} 1$ & \multirow{3}{*}{0,730} & \multirow{3}{*}{0,000} & 0,869 & \multirow{3}{*}{0,853} \\
\hline & & 2. $\mathrm{AB} 2$ & & & 0,897 & \\
\hline & & 3. $\mathrm{AB} 3$ & & & 0,879 & \\
\hline \multirow{4}{*}{7} & \multirow{4}{*}{$\begin{array}{l}\text { Purchase } \\
\text { intention }\end{array}$} & 1. PI1 & \multirow{4}{*}{0,791} & & 0,887 & \\
\hline & & 2. PI2 & & & 0,914 & \\
\hline & & 3. PI3 & & 0,000 & 0,888 & 0,895 \\
\hline & & 4. PI4 & & & 0,799 & \\
\hline
\end{tabular}

The respondents in this study vary in percentage as shown in Table III: male respondents were $29 \%$ while female respondents dominated the survey. This is indicated by 186 female respondents (71\%) who were aged between 24 and 27 years (40\%). With regard to education, 
respondents with bachelor's degree dominate the survey $(63 \%)$.

TABLE III. PRofile of RESPONDENTS GENDER, AGE, AND EDUCATION

\begin{tabular}{|c|c|c|}
\hline & Percentage & Frequency \\
\hline \multicolumn{3}{|c|}{ Gender } \\
\hline Male & $28 \%$ & 74 \\
\hline Female & $72 \%$ & 186 \\
\hline \multicolumn{3}{|c|}{ Age } \\
\hline $16-19$ & $10 \%$ & 27 \\
\hline $20-23$ & $28 \%$ & 72 \\
\hline $24-27$ & $40 \%$ & 104 \\
\hline $28--31$ & $13 \%$ & 34 \\
\hline $32--35$ & $9 \%$ & 23 \\
\hline \multicolumn{3}{|c|}{ Education } \\
\hline High School & $31 \%$ & 80 \\
\hline Bachelor & $63 \%$ & 163 \\
\hline Master & $7 \%$ & 17 \\
\hline
\end{tabular}

Private company employees accounted for $37 \%$, while students accounted for $36 \%$ of the total respondents. Respondents with monthly expenses of Rp1,000,000$\mathrm{Rp} 3,000,000$ accounted for the largest percentage of $32 \%$ as shown in Table IV.

TABLE IV. PROFILE OF RESPONDENTS OCCUPATION AND MONTHLY SPENDING

\begin{tabular}{|c|c|c|}
\hline & Percentage & Frequency \\
\hline \multicolumn{3}{|c|}{ Occupation } \\
\hline Private Company Employee & $37 \%$ & 96 \\
\hline Other & $11 \%$ & 29 \\
\hline Teacher/Professor & $1 \%$ & 3 \\
\hline Entrepreneur & $5 \%$ & 14 \\
\hline BUMN Employee & $3 \%$ & 8 \\
\hline Student & $36 \%$ & 93 \\
\hline Civil Servant & $2 \%$ & 6 \\
\hline Doctor & $4 \%$ & 11 \\
\hline \multicolumn{3}{|c|}{ Monthly Spending } \\
\hline$<$ Rp1.000.000 & $22 \%$ & 56 \\
\hline Rp1.000.000-Rp3.000.000 & $32 \%$ & 84 \\
\hline Rp3.000.000-Rp5.000.000 & $22 \%$ & 57 \\
\hline Rp5.000.000-Rp7.000.000 & $11 \%$ & 29 \\
\hline$>$ Rp7.000.000 & $13 \%$ & 34 \\
\hline
\end{tabular}

Further data processing used SEM. Confirmatory Factor Analysis (CFA) was conducted to test the validity and reliability of variables used based on the measurement model analysis. According to Hair et al. [58], the variable can be judged as valid if it has a standardized loading factor greater than or equal to 0.50 . Furthermore, Hair et al. [59] state that the reliability of a variable has a construct reliability value greater than or equal to 0.7 and an extracted variance value greater than or equal to 0.5 .

TABLE V. STANDARDIZED LOADING FACTOR, CONSTRUCT RELIABILITY, AND VARIANCE EXTRACTED

\begin{tabular}{|c|c|c|c|c|c|}
\hline & Std. Loading & Error & Std. Loading ${ }^{2}$ & CR & VE \\
\hline EA1 & 0.65 & 0.58 & 0.4225 & \multirow{4}{*}{0.804} & \multirow{4}{*}{0.5815} \\
\hline EA2 & 0.74 & 0.45 & 0.5476 & & \\
\hline EA3 & 0.88 & 0.22 & 0.7744 & & \\
\hline Total & 2.27 & 1.25 & 1.7445 & & \\
\hline INF1 & 0.87 & 0.25 & 0.7569 & \multirow{5}{*}{0.874} & \multirow{5}{*}{0.6361} \\
\hline INF2 & 0.82 & 0.33 & 0.6724 & & \\
\hline INF3 & 0.84 & 0.30 & 0.7056 & & \\
\hline INF4 & 0.64 & 0.59 & 0.4096 & & \\
\hline Total & 3.17 & 1.47 & 2.5445 & & \\
\hline AC1 & 0.86 & 0.26 & 0.7396 & \multirow{5}{*}{0.918} & \multirow{5}{*}{0.7368} \\
\hline AC2 & 0.82 & 0.32 & 0.6724 & & \\
\hline AC3 & 0.92 & 0.16 & 0.8464 & & \\
\hline AC4 & 0.83 & 0.32 & 0.6889 & & \\
\hline Total & 3.43 & 1.06 & 2.9473 & & \\
\hline ENT1 & 0.87 & 0.24 & 0.7569 & \multirow{4}{*}{0.917} & \multirow{4}{*}{0.7867} \\
\hline ENT2 & 0.87 & 0.25 & 0.7569 & & \\
\hline ENT3 & 0.92 & 0.15 & 0.8464 & & \\
\hline Total & 2.66 & 0.64 & 2.3602 & & \\
\hline AAD1 & 0.87 & 0.24 & 0.7569 & \multirow{5}{*}{0.899} & \multirow{5}{*}{0.6916} \\
\hline AAD2 & 0.88 & 0.23 & 0.7744 & & \\
\hline AAD3 & 0.75 & 0.44 & 0.5625 & & \\
\hline AAD4 & 0.82 & 0.33 & 0.6724 & & \\
\hline Total & 3.32 & 1.24 & 2.7662 & & \\
\hline AB1 & 0.81 & 0.34 & 0.6561 & \multirow{4}{*}{0.901} & \multirow{4}{*}{0.7531} \\
\hline AB2 & 0.92 & 0.15 & 0.8464 & & \\
\hline AB3 & 0.87 & 0.24 & 0.7569 & & \\
\hline Total & 2.60 & 0.73 & 2.2594 & & \\
\hline PI1 & 0.85 & 0.27 & 0.7225 & \multirow{5}{*}{0.862} & \multirow{5}{*}{0.6145} \\
\hline PI2 & 0.90 & 0.19 & 0.8100 & & \\
\hline PI3 & 0.66 & 0.53 & 0.4356 & & \\
\hline PI4 & 0.70 & 0.51 & 0.4900 & & \\
\hline Total & 3.11 & 1.50 & 2.4581 & & \\
\hline
\end{tabular}

According to Table $\mathrm{V}$, the standard loading factor value greater than or equal to 0.5 , construct reliability value greater than or equal to 0.7 , and an extracted variance value greater than or equal to 0.5 . Therefore, all measures used in this research are reliable. 
TABLE VI GOODNESS-OF-FIT TEST RESULT

\begin{tabular}{|c|c|c|c|}
\hline $\begin{array}{c}\text { Goodness } \\
\text {-of-fit }\end{array}$ & $\begin{array}{c}\text { Acceptable Value of Goodness- } \\
\text { of-Fit }\end{array}$ & $\begin{array}{c}\text { Result of } \\
\text { Goodness- } \\
\text { of-Fit }\end{array}$ & Notes \\
\hline GFI & GFI $\geq 0.90$ is good fit & 0.83 & Poor fit \\
\hline RMR & $\mathrm{RMR} \leq 0.50$ is good fit & 0.081 & Good fit \\
\hline RMSEA & $0.05<\mathrm{RMSEA} \leq 0.08$ is good fit & 0.077 & Good fit \\
\hline ECVI & $\begin{array}{l}\text { ECVI model approaching value } \\
\text { ECVI saturated }\end{array}$ & $\begin{array}{l}\text { ECVI } \\
\text { Model } \\
91.50 \\
\text { ECVI } \\
\text { Saturated } \\
2.51 \\
\end{array}$ & Poor fit \\
\hline TLI/NNFI & $\mathrm{NNFI} \geq 0.90$ is good fit & 0.98 & Good fit \\
\hline NFI & $\mathrm{NFI} \geq 0.90$ is good fit & 0.97 & Good fit \\
\hline AGFI & $\mathrm{AGFI} \geq 0.90$ is good fit & 0.79 & Poor fit \\
\hline RFI & $\mathrm{RFI} \geq 0.90$ is good fit & 0.97 & Good fit \\
\hline IFI & IFI $\geq 0.90$ is good fit & 0.98 & Good fit \\
\hline CFI & $\mathrm{CFI} \geq 0.90$ is good fit & 0.98 & Good fit \\
\hline
\end{tabular}

The goodness-of-fit test is used to test the measurement model of the study, which include the absolute-fit measures, incremental fit measures, and parsimonious fit measures [58][60]. According to Table VI, out of 10 goodness-of-fit standards, this study has seven good fitting results. Therefore, the hypothesis can be tested using the t-value of the research model formed.

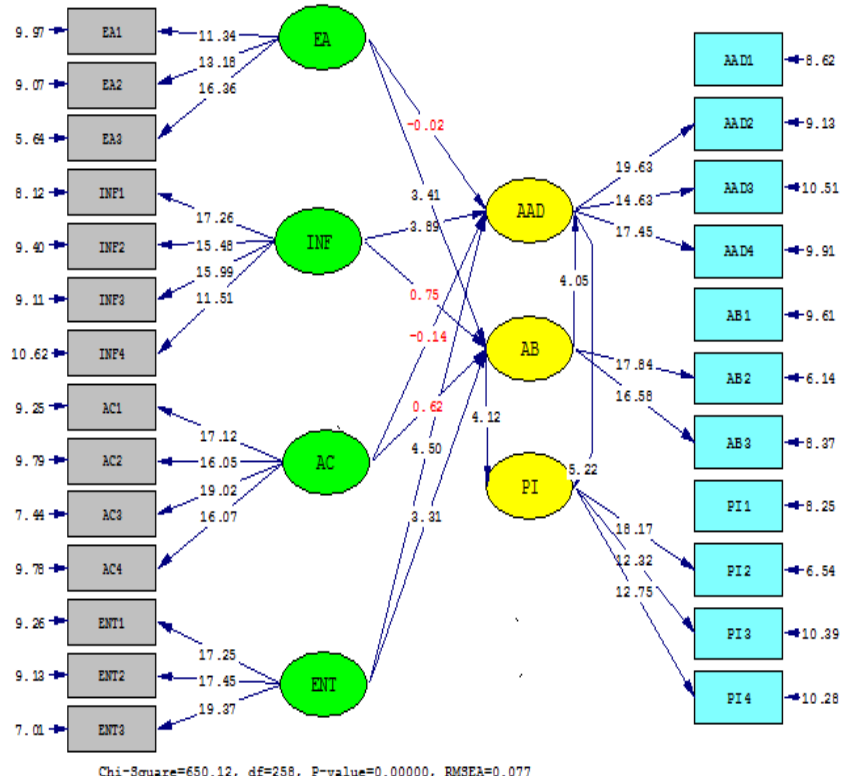

Fig. 2. Structural Model (T-Values)

Based on data processing, four hypotheses do not meet the absolute $t$-value above 1.645 , hence the following are insignificant: the effect of emotional appeals on the attitude toward the advertising, the effect of informativeness on the attitude toward the brand, the effect of advertising creativity toward the attitude toward the advertising, and the effect of advertising creativity on the attitude toward the brand. Table VII further explains the hypothesis testing results.
TABLE VII. Hypothesis Testing Result

\begin{tabular}{|c|c|c|c|c|}
\hline Hypothesis & T-Value & Significant & $\begin{array}{l}\text { Estimate } \\
\text { Value }\end{array}$ & $\begin{array}{l}\text { Supported/Not } \\
\text { supported }\end{array}$ \\
\hline $\begin{array}{l}\text { Emotional } \\
\text { Appeals } \rightarrow \\
\text { Attitude toward } \\
\text { the Advertising }\end{array}$ & -0.02 & Insignificant & -0.00 & Not supported \\
\hline $\begin{array}{l}\text { Emotional } \\
\text { Appeals } \rightarrow \\
\text { Attitude toward } \\
\text { the Brand }\end{array}$ & 3.41 & Significant & 0.3 & Supported \\
\hline $\begin{array}{l}\text { Informativeness } \\
\rightarrow \quad \text { Attitude } \\
\text { toward the } \\
\text { Advertising }\end{array}$ & 3.89 & Significant & 0.34 & Supported \\
\hline $\begin{array}{l}\text { Informativeness } \\
\rightarrow \quad \text { Attitude } \\
\text { toward the } \\
\text { Brand }\end{array}$ & 0.75 & Insignificant & 0.09 & Not Supported \\
\hline $\begin{array}{l}\text { Advertising } \\
\text { Creativity } \rightarrow \\
\text { Attitude toward } \\
\text { the Advertising }\end{array}$ & -0.14 & Insignificant & -0.01 & Not supported \\
\hline $\begin{array}{l}\text { Advertising } \\
\text { Creativity } \rightarrow \\
\text { Attitude toward } \\
\text { the Brand }\end{array}$ & 0.62 & Insignificant & 0.08 & Not Supported \\
\hline $\begin{array}{l}\text { Entertainment } \\
\rightarrow \quad \text { Attitude } \\
\text { toward the } \\
\text { Advertising }\end{array}$ & 4.50 & Significant & 0.44 & Supported \\
\hline $\begin{array}{l}\text { Entertainment } \\
\rightarrow \text { Attitude } \\
\text { toward the } \\
\text { Brand }\end{array}$ & 3.31 & Significant & 0.41 & Supported \\
\hline $\begin{array}{l}\text { Attitude toward } \\
\text { the Brand } \rightarrow \\
\text { Attitude toward } \\
\text { the Advertising }\end{array}$ & 4.05 & Significant & 0.25 & Supported \\
\hline $\begin{array}{l}\text { Attitude toward } \\
\text { the Advertising } \\
\rightarrow \quad \text { Purchase } \\
\text { Intention }\end{array}$ & 5.22 & Significant & 0.48 & Supported \\
\hline $\begin{array}{l}\text { Attitude toward } \\
\text { the Brand } \rightarrow \\
\text { Purchase } \\
\text { Intention }\end{array}$ & 4.12 & Significant & 0.38 & Supported \\
\hline
\end{tabular}

The most powerful impact between variables that measure ad exposure is that of entertainment and informativeness on attitude toward the advertising. In addition, compared to the influence of attitude toward the brand toward purchase intention, the attitude toward the advertising has a stronger influence on purchase intention. The insignificant relations between variable emotional appeals on the attitude toward the advertising can be a result of the use of emotion in consumer-dependent advertising in the purchase of a particular product or service[61]. In other words, not all types of emotion used in the ad will have the same effect on the audience and the consumer. Moreover, the insignificant relation between informativeness on the attitude toward the brand is a result of the insufficient information provided in the ads on Instagram. This is insufficient; therefore, potential customers should conduct further evaluation of the advertiser's product or brand on other platforms. Other insignificant relation between advertising creativity toward the attitude toward the advertising and 
attitude toward the brand are a result of different perception creativity between advertisers or marketers and consumers [62].

\section{CONCLUSIONS AND MANAGERIAL IMPLICATION}

Advertising exposures such as emotional appeals, informativeness, and entertainment play a significant role in influencing the attitude toward advertising and brand. Among the four advertising exposures variables, informativeness only affects the attitude toward the advertising, while the entertainment affects both. The most important feature of exposure to advertising is entertainment. As one of the reasons that users spend a long time on social media is to find entertainment, entertaining ads, and provide fun for the audience, it can form a positive attitude toward advertising and brand advertisers. However, advertising creativity does not affect consumer attitudes either on the advertisement or on the brand. This could happen due to different perceptions between the audience and the creative team behind the advertising.

Emotional appeals greatly influence the attitude toward the brand. Although the ads that appear on Instagram vary for each user, the emotional appeals of the ads on Instagram play an important role in shaping a positive attitude toward the brand. Emotional appeals advertising is an important aspect because it plays a major role in helping the audience and consumers in understanding and receiving advertising. Informativeness of advertising is also important to form a positive attitude toward the ad itself. Attitude toward a brand owned by consumers before seeing ads on Instagram also help in shaping a positive attitude toward the advertising. With regard to purchase intention arising from a positive attitude toward advertising and brand advertisers, attitude toward the advertising has a greater influence on bringing about the purchase intentions of consumers than the attitude toward the brand.

This study does not use any specific example of the advertising material, instead it uses the respondents' memory recall of the advertisement seen on Instagram. Therefore, future research can use advertising stimuli that do not have a brand effect to avoid influencing the perception of respondents to the advertising. In addition to stimulus, further research can also emphasize on certain types of products. Further research can add other variables such as privacy and seek relationships with perceived herd behavior and subjective norms toward attitude toward the advertising and the brand. The sample size can be increased for better results from data processing. In addition, the differences in the number of female and male respondents in this study can be used for subsequent research to use gender as a control variable to see their evaluation of the variables used.

Managerial implications of this study area are when creating advertisements for Instagram, companies need to pay attention to the emotional appeals, informativeness, and entertainment aspects of the ads. Moreover, the emotional appeals of an advertisement play an important role in building the attitude toward the brand. Companies can choose positive or negative emotions that consumers want to feel. However, the use of negative emotions in advertising needs to be done with caution, because when the company triggers negative emotions appearing in consumers' minds, the products offered should be able to provide solutions to emerging emotions that can trigger consumers to buy and use products offered by the brand advertisers. Furthermore, companies should highlight entertainment aspects because it can increase the positive attitude toward the ads themselves and on the brand and preferred by consumers. This aspect is very important to achieve the effectiveness of the advertising to further affect the revenue and ROI of marketing activities undertaken by the company.

\section{REFERENCES}

[1] Liu, J., Li, C., Ji, Y. G., North, M., \& Yang, F. (2017). Like it or not: The Fortune 500' s Facebook strategies to generate users' electronic word-of-mouth. Computers in Human Behavior, 73, 605-613.

[2] Kaplan, A. M., \& Haenlein, M. (2010). Users of the world, unite! The challenges and opportunities of Social Media. Business Horizons, 53, 59-68.

[3] Ellison, N. B., Steinfield, C., \& Lampe, C. (2007). The benefits of facebook "friends:" Social capital and college students' use of online social network sites. Journal of Computer-Mediated Communication, 12, 1143-1168.

[4] eMarketer. (2015). Indonesia to enjoy robust growth across Ad media. https://www.emarketer.com/Article/Indonesia-Enjoy-Robust-GrowthAcross-Ad-Media/1012978

[5] Mukherjee, K., \& Banerjee, N. (2017). Effect of social networking advertisements on shaping consumers' attitude. Global Business Review, 18, 1291-1306.

[6] Nielsen. (2013). The paid social media advertising report 2013. http://www.nielsen.com/id/en/insights/reports/2013/the-paid-socialmedia-advertising-report-2013.html

[7] eMarketer. (2017). How social media marketers can leverage marketing technology. https://www.emarketer.com/Article/HowSocial-Media-Marketers-Leverage-Marketing-Technology/1016817.

[8] Hennig-Thurau, T., Gwinner, K. P., Walsh, G., \& Gremler, D. D. (2004). Electronic word-of-mouth via consumer-opinion platforms: What motivates consumers to articulate themselves on the Internet? Journal of Interactive Marketing, 18, 38-52.

[9] Mangold, W. G., \& Faulds, D. J. (2009). Social media: The new hybrid element of the promotion mix. Business Horizons, 52, 357365.

[10] Lee, J., \& Hong, I. B. (2016). Predicting positive user responses to social media advertising: The roles of emotional appeal, informativeness, and creativity. International Journal of Information Management, 36, 360-373.

[11] Casey, S. (2017). 2016 Nielsen Social Media Report. http://www.nielsen.com/us/en/insights/reports/2017/2016-nielsensocial-media-report.html

[12] Demers, J. (2017). Instagram is popular, but does it have a high ROI? https://www.forbes.com/sites/jaysondemers/2017/11/06/instagram-ispopular-but-does-it-have-a-high-roi/\#4e5ee1b367a9

[13] Tim Instagram Business. (2017). 2 Juta Pengiklan Bulanan di Instagram. https://business.instagram.com/blog/welcoming-twomillion-advertisers

[14] Adi, A., \& Hidayat, A. (2017). 45 Juta Pengguna Instagram, Indonesia Pasar Terbesar di Asia. Tempo.Co, $2-4$. https://bisnis.tempo.co/read/894605/45-juta-pengguna-instagramindonesia-pasar-terbesar-di-asia

[15] eMarketer. (2016). Leading Instagram activities of instagram users ages 16-35 in Indonesia, Jan 2016 (\% of respondents). http://www.emarketer.com/Chart/Leading-Instagram-Activities-ofInstagram-Users-Ages-16-35-Indonesia-Jan-2016-ofrespondents/185378

[16] Dellarocas, C., Zhang, X., \& Awad, N. F. (2007). Exploring the value of online product reviews in forecasting sales: The case of motion pictures. Journal of Interactive Marketing, 21, 23-45.

[17] Godes, D., \& Mayzlin, D. (2004). Using online conversations to study word-of-mouth communication. Marketing Science, 23, 545-560.

[18] Minton, E., Lee, C., Orth, U., Kim, C.-H., \& Kahle, L. (2012). Sustainable marketing and social media. A cross-country analysis of motives for sustainable behaviors. Journal of Advertising, 41, 69-84.

[19] Van Doorn, J., Lemon, K. N., Mittal, V., Nass, S., Pick, D., Pirner, P., \& Verhoef, P. C. (2010). Customer engagement behavior: Theoretical 
foundations and research directions. Journal of Service Research, 13, 253-266.

[20] Dehghani, M., Niaki, M. K., Ramezani, I., \& Sali, R. (2016). Evaluating the influence of YouTube advertising for attraction of young customers. Computers in Human Behavior, 59, 165-172.

[21] Hensel, K., \& Deis, M. H. (2010). Using social media to increase advertising and improve marketing. The Entrepreneurial Executive, 15, 87-98.

[22] Internet Advertising Bureau. (2009). Internet advertising revenues surpass \$23 Billion in , 08, reaching record high https:/www.iab.com/news/internet-advertising-revenues-surpass-23billion-08-reaching-record-high/

[23] Rodgers, S., \& Thorson, E. (2017). Digital Advertising: Theory and Research 3rd Edition. Routledge, Taylor \& Francis Group, New York.

[24] Chandra, B., Goswami, S., \& Chouhan, V. (2012). Investigating attitude towards online advertising on social media-an empirical study. Management Insight, VIII.

[25] Duffett, R. G. (2015). Facebook advertising' $s$ influence on intention-to-purchase and purchase amongst Millennials. Internet Research, 25, 498-526.

[26] Zhang, H., Sun, J., Liu, F., \& G. Knight, J. (2014). Be rational or be emotional: advertising appeals, service types and consumer responses. European Journal of Marketing, 48, 2105-2126.

[27] Behboudi, M., Vazifehdoust, H., Najafi, K., \& Najafi, M. (2014) Using rational and emotional appeals in online advertisements for Muslim customers. Journal of Islamic Marketing, 5, 97-124.

[28] Alhabash, S., McAlister, A. R., Hagerstrom, A., Quilliam, E. T., Rifon, N. J., \& Richards, J. I. (2013). Between likes and shares: effects of emotional appeal and virality on the persuasiveness of anticyberbullying messages on facebook. Cyberpsychology, Behavior, and Social Networking, 16, 175-182.

[29] Rosenkrans, G. (2010). Maximizing user interactivity through banner ad design. Journal of Promotion Management, 16, 265-287.

[30] Taylor, G. (2011). The informativeness of on-line advertising. International Journal of Industrial Organization, 29, 668-677.

[31] Hamilton, S. F. (2009). Informative advertising in differentiated oligopoly markets. International Journal of Industrial Organization, 27, 60-69.

[32] Chen, Q., \& Wells, W. D. (1999). Attitude toward the site. Journal of Advertising Research, 39.

[33] Ducoffe, R. H., \& Curlo, E. (2000). Advertising value and advertising processing How Consumers Assess the Value of. Journal of Marketing Communications, 6, 247-262.

[34] Ducoffe, R. H. (1995). How Consumers assess the value of advertising. Journal of Current Issues \& Research in Advertising, 17, $1-18$.

[35] Smith, R. E., \& Yang, X. (2004). Toward a general theory of creativity in advertising: Examining the role of divergence. Marketing Theory, 4, 31-58.

[36] Reinartz, W., \& Peter, S. (2013). Creativity in advertising: when it works and when it doesn, t. Retrieved from https://hbr.org/2013/06/creativity-in-advertising-when-it-works-andwhen-it-doesnt

[37] Smith, R. E., Mackenzie, S. B., Buchholz, L. M., \& Darley, W. K. (2007). Modeling the Determinants and Effects of Creativity in Advertising. Marketing Science, 26, 819-833. https://kelley.iu.edu/Faculty/Marketing/lbuchhol/publications/MS Modeling Creativity 2007.PDF

[38] Muntinga, D. G., Moorman, M., \& Smit, E. G. (2011). Introducing COBRAs. International Journal of Advertising, 30, 13-46.

[39] Taylor, D., Lewin, J., \& Strutton, D. (2011). Friends, fans, and followers: Do ads work on social networks? How gender and age shape receptivity. Journal of Advertising Research, 51.

[40] Wang, Y., \& Sun, S. (2010). Assessing beliefs, attitudes, and behavioral responses toward online advertising in three countries. International Business Review, 19, 333-344.
[41] Belch, G. E., \& Belch, M. A. (2015). Advertising and promotion: An integrated marketing communications perspective. McGraw-Hill Education.

[42] MacKenzie, S. B., \& Lutz, R. J. (1989). An empirical examination of the structural antecedents of attitude toward the ad in an advertising pretesting context. Journal of Marketing, 53, 48-65.

[43] Davtyan, D., \& Cunningham, I. (2017). An investigation of brand placement effects on brand attitudes and purchase intentions: Brand placements versus TV commercials. Journal of Business Research, 70, 160-167.

[44] Kotler, P., \& Keller, K. L. (2012). Marketing Management (14th ed.). Prentice Hall.

[45] Keller, K. L. (2008). Strategic Brand Management. Brand, 58.

[46] Rosselli, F., Skelly, J. J., \& Mackie, D. M. (1995). Processing rational and emotional messages: The cognitive and affective mediation of persuasion. Journal of Experimental Social Psychology.

[47] Resnik, A., \& Stern, B. L. (1977). An Analysis of Information Content in Television Advertising. Journal of Marketing, 41(1), 50.

[48] Logan, K., Bright, L. F., \& Gangadharbatla, H. (2012). Facebook versus television: advertising value perceptions among females. Journal of Research in Interactive Marketing, 6, 164-179.

[49] Davis, M. H. (1983). Measuring individual differences in empathy: Evidence for a multidimensional approach. Journal of Personality and Social Psychology, 44, 113-126.

[50] Edson, J., \& Stern, B. B. (2003). Sympathy and empathy: Emotional responses to advertising dramas. Journal of Consumer Research, 29, 566-578.

[51] Pavlou, Liang, \& Xue. (2007). Understanding and mitigating uncertainty in online exchange relationships: A principal-agent perspective. MIS Quarterly, 31(1), 105.

[52] Haberland, G. S., \& Dacin, A. D. (1992). The development of a measure to assess viewers judgments of the creativity of an advertisement: A preliminary study. Advances in Consumer Research, 19, 817-825.

[53] Tsang, M. M., Ho, S. C., \& Liang, T.-P. (2004). Consumer attitudes toward mobile advertising: An empirical study. International Journal of Electronic Commerce, 8, 65-78.

[54] Huang, Su, Zhou, \& Liu, 2013

[55] Colliander, J., \& Dahlén, M. (2011). Following the fashionable friend: The power of social media. Journal of Advertising Research, 51, 313-320.

[56] Mikalef, P., Giannakos, M., \& Pateli, A. (2013). Shopping and wordof-mouth intentions on social media. Journal of Theoretical and Applied Electronic Commerce Research, 8, 17-34.

[57] Malhotra, N. K., \& Birks, D. F. (2007). Marketing Research an Applied Approach (3rd ed.). Prentice Hall. https://books.google.com/books?id=VYj0AQAAQBAJ\&pgis=1

[58] Hair, J. F., Anderson, R. E., Tatham, R. L., \& Black, W. C. (2010). Multivariate Data Analysis (7th Edition). Uppersaddle River, New Jersey: Pearson Education International.

[59] Hair, J. F., Anderson, R. E., Tatham, R. L., \& Black, W. C. (1998). Multivariate data analysis with readings (5nd ed.). Prentice-Hill, Upper Saddle River.

[60] Wijanto, S. H. (2008). Structural Equation Modeling dengan LISREL 8.8: Konsep dan Tutorial. Yogyakarta: Graha Ilmu.

[61] Rucker, D. (2017). Emotion in Advertising: The difference between a spark and a backfire. https://www.forbes.com/sites/derekrucker/2017/ 10/05/emotion-in-advertising-the-difference-between-a-spark-and-abackfire/\#2ce21a2f31e5

[62] West, D. C., Kover, A. J., \& Caruana, A. (2008). Practitioner and Customer Views of Advertising Creativity: Same concept, different meaning? Journal of Advertising, 37, 35-46. 